\title{
S NOTE on Dates and Names
}

Dates in this book are drawn from the sources on which this study is based, which reflect the use of the Julian calendar in Russia during the early modern period. The Julian calendar numbered years from the traditional date of the creation of the world (5508 BCE), starting on September 1. Dates in this book are frequently presented in two forms: anno mundi and anno domini. Thus Tsar Mikhail Fedorovich, the first tsar of the Romanov dynasty, was married for the first time in the year 7133/1624. Furthermore, in the sixteenth and seventeenth centuries the Julian calendar was either nine or ten days behind the Gregorian calendar (nine days before March 1500, and ten days after). Thus the full date of Mikhail Fedorovich's wedding, for example, might be rendered September 18/28, 7133/1624, though typically this is simplified in the pages below to September 18, 1624 (the day in Julian, and year in anno domini).

Names are also rendered as they appear in contemporary sources. Variant spellings of names are preserved, though names during and after Peter the Great's reign (1682-1725) appear in the usual English equivalents (Peter for Pëtr or Pyotr; Catherine for Ekaterina, and so on), as is the convention. Patronymics reflected social rank in Muscovy and these are preserved whenever possible in the pages below. Grand princes, tsars, and the highest-ranking courtiers had patronymics ending in "-ovich," "-evich," or "-ich” (for males), as all Russian men do today. Grand princesses, tsaritsas, and the highestranking women of the court had patronymics ending in "-ovna” or "-evna," as, again, all Russian women do today. Lesser-ranking servitors had patronymics in "syn" (son of) and their wives and daughters in "doch" (daughter of). Thus, we find Prince Ivan Vasil'evich Golitsyn, but Denis Timofeev syn Ul'ianov. The first two wives of Tsar Mikhail Feodorovich likely had different patronymics, at least before their weddings: his first wife, a princess, was Mariia Vladimirovna Dolgorukova; his second, the daughter of a middle-level gentryman, was likely born Evdokiia Luk'ianova doch' Streshneva (before dropping the "doch" " and picking up the "-ovna" on becoming 
tsaritsa). All names, titles, and terms, whatever their form, are presented in the standard modified Library of Congress transliteration system (omitting the unsightly ligatures over certain letter combinations). Finally, terms that do not translate naturally into English (such as okol'nichii) are left in the original, with a definition at the first instance. 
